\title{
POTENTIAL OF PREDICTION QUANTIFICATION AND TRENDS IN TRANSPORT REQUIREMENTS AS TOOL OF TRANSPORT MANAGEMENT AND DEVELOPMENT
}

\author{
Ján Ondruš $\check{s}^{1}$ Jana Dicová ${ }^{2}$ \\ ${ }^{1}$ University of Zilina in Zilina, Faculty of Operation and Economics of Transport and Communications, \\ Department of Road and Urban Transport \\ Univerzitná 8251/1, SK-010 26 Žilina, Slovak Republic \\ Phone: +421 415133 526, E-mail: jan.ondrus@fpedas.uniza.sk \\ ${ }^{2}$ University of Zilina in Zilina, Faculty of Management Science and Informatics, \\ Department of Management Theories \\ Univerzitná 8251/1, SK-010 26 Žilina, Slovak Republic \\ Phone: +421 415134 077. E-mail: jana.dicova@fri.uniza.sk
}

\begin{abstract}
The basic aim of managers in transport is to preserve and expand their share of the transport market. This should be done through prioritising quality and customer service, preservation and expansion field of transport enterprise activity to transport market on the basic of priority orientation to quality and customer, maintaining transport networks and applying the latest knowledge from research. It should also involve making a contribution to favourable indicators of economic activity, and a consideration of environmental change. This paper deals with customer requirements, the possibility of quantifying customer requirements and the recognition of future trends on the basis of assessments of recent quantitative results and the application of managers' knowledge and techniques.
\end{abstract}

Keywords: transport, prediction, region, transport performance, number of passengers, mass public transport (MPT)

\section{Introduction}

Transport is a phenomenon that consists of a large number of successive sub-events forming a complex whole. Human activities are always a key to this activity, because transport (except for planning, design, organization, management) involves controlling the movement of vehicles in space and time [3].

The competitiveness of a service provided by a transport enterprise is likely to improve if the enterprise is interested in meeting basic customer needs regarding safety, quality, reliability and cost. For this reason it is important that the carrier should concentrate on the continuous monitoring of customers' requirements and indicators of transport performance at and between different locations.

\section{Quantified Performance of Mass Public Transport (MPT)}

Passenger transport is a necessary consequence of the spatial distribution of activities and consequence of the adoption, use and settlement of the development environment. Passenger transport enables vital communication links generated by the interaction of the basic functions of the city (residence, workplace, cultural centre) to be maintained $[2,7]$.

Transport requirements of the population have significant effects on the way people live. The function of public transport is to provide transport connections to meet public demand as far as is practicable. At the same time, it is important that public transport organisations should be as efficient as possible to limit the demand for regional resources [6].

The quantification of customers' requirements in regard to transport processes can be realised by transport indicators (number of passengers and transport performance). Trends can be identified by the progression of indicators that change with respect to time function and dependence on parameters. These represent trend tendencies.

The Slovak Republic can be divided into the following regions (Fig. 1):

$=$ Bratislava region,

$=$ Trnava region, 
$=$ Trencin region,

$=$ Nitra region,

= Zilina region,

= Banska Bystrica region,

$=$ Kosice region,

= Presov region.

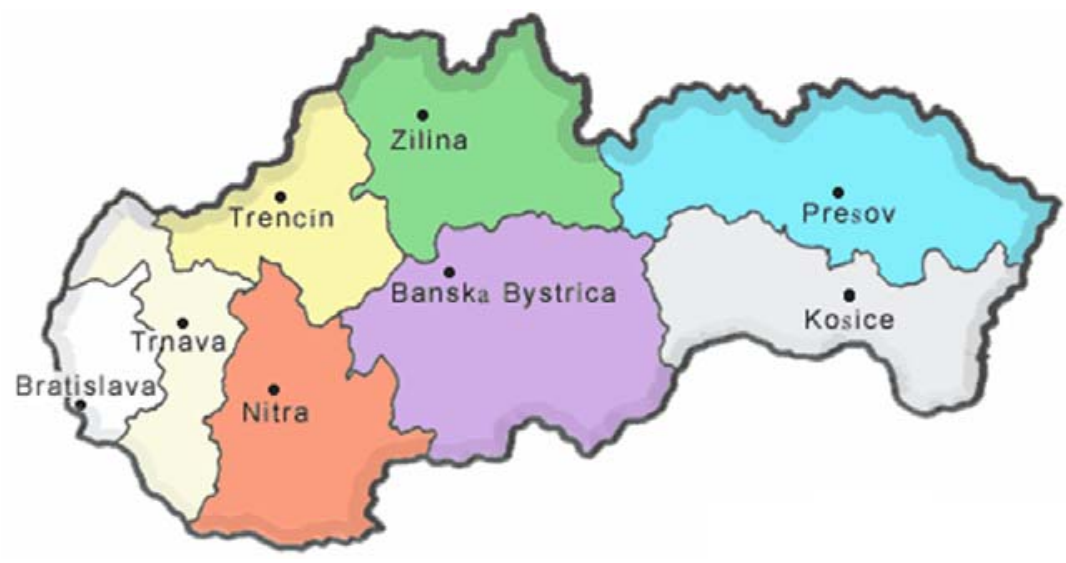

Figure 1. Regions of the Slovak Republic [9]

The Slovak Republic is located in Central Europe with surface area of $49035.56 \mathrm{~km}^{2}$. The number of inhabitants is 5410836 (of which females $51.3 \%$ ). The capital city is Bratislava with 415589 inhabitants. The Slovak Republic consists of 8 regions. In 2012, the most inhabitants lived in Presov region ( $817382-15.1 \%$ of the total population). On the contrary, the least inhabitants lived in Trnava region (556 $577-10.3 \%$ of the total population). Banska Bystrica region is the largest from all of them with surface area of $9454.32 \mathrm{~km}^{2}$ and with the lowest population density per $\mathrm{km}^{2}$ (69.6). Conversely, the smallest region is Bratislava region $\left(2052.62 \mathrm{~km}^{2}\right)$, in its turn there is the highest population density per $\mathrm{km}^{2}$ (298.5). The average population density per $1 \mathrm{~km}^{2}$ in the Slovak Republic is 110.3 .

Table 1. The Basic Data about Slovak Regions

\begin{tabular}{|c|c|c|c||}
\hline Region & The number of inhabitants & Area in $\mathbf{~ k m}^{2} \mathbf{b y ~ r e g i o n ~}$ & Population density per km ${ }^{2}$ \\
\hline \hline Bratislava & 612682 & 2052,62 & 298,5 \\
\hline Trnava & 556577 & 4146,40 & 134,2 \\
\hline Trencin & 593159 & 4501,98 & 131,8 \\
\hline Nitra & 688400 & 6343,78 & 108,5 \\
\hline Zilina & 690121 & 6808,58 & 101,4 \\
\hline Bansk Bystrica & 658490 & 9454,32 & 69,6 \\
\hline Kosice & 794025 & 6754,51 & 117,6 \\
\hline Presov & 817382 & 8973,37 & 91,1 \\
\hline Total & $\mathbf{5 4 1 0 8 3 6}$ & $\mathbf{4 9 0 3 5 , 5 6}$ & $\mathbf{1 1 0 , 3}$ \\
\hline
\end{tabular}

Data are on 31.12 .2012 [8]

The number of passengers using public transport for their everyday trips has been decreased during the last years in the Slovak Republic. This development is very similar to the development in most of the countries in Europe in the last decades [7].

The trend regarding the number of passengers in several regions of the Slovak Republic for the period 2001-2012 is shown in Table 2. From a long-term perspective, the trend in the number of 
passengers shows a decrease almost every year for every region (or about the same value), with the exception of the Trencin region in the year 2005 and the Nitra region in the year 2008.

Table 2. Number of Passengers in the Enterprises, which are Specialised in Road Transport (Thousands of Passengers)

\begin{tabular}{|c|c|c|c|c|c|c|c|c|c|}
\hline & \multicolumn{9}{|c|}{ Number of passengers (thousands of passengers) } \\
\hline Year Region & Bratislava & Trnava & Trencin & Nitra & Zilina & $\begin{array}{l}\text { Banska } \\
\text { Bystrica }\end{array}$ & Kosice & Presov & Total \\
\hline 2001 & 22743 & 47832 & 95495 & 85399 & 89076 & 104041 & 52895 & 68964 & 566445 \\
\hline 2002 & 22549 & 45047 & 90024 & 75503 & 86408 & 98533 & 49858 & 68691 & 536613 \\
\hline 2003 & 20220 & 40354 & 81651 & 65293 & 79103 & 95775 & 45501 & 65809 & 493706 \\
\hline 2004 & 19014 & 37772 & 77397 & 62815 & 73437 & 87886 & 42621 & 60830 & 461772 \\
\hline 2005 & 18229 & 37549 & 85019 & 61436 & 69187 & 79999 & 41219 & 56818 & 449456 \\
\hline 2006 & 17658 & 36783 & 65209 & 58066 & 66704 & 63824 & 41657 & 53369 & 403270 \\
\hline 2007 & 17094 & 35145 & 62301 & 58101 & 62926 & 59487 & 40488 & 49095 & 384637 \\
\hline 2008 & 16934 & 33071 & 59151 & 60106 & 58975 & 53745 & 37667 & 45870 & 365519 \\
\hline 2009 & 15722 & 29027 & 53177 & 54651 & 52904 & 46020 & 32037 & 39604 & 323142 \\
\hline 2010 & 15748 & 28437 & 51506 & 53866 & 50332 & 45020 & 29336 & 38472 & 312717 \\
\hline 2011 & 15564 & 27450 & 48242 & 50175 & 49745 & 42692 & 29341 & 36370 & 299579 \\
\hline 2012 & 14543 & 26441 & 44747 & 48138 & 50918 & 41367 & 28046 & 35028 & 289228 \\
\hline
\end{tabular}

Source: The Statistical Office of the SR

The greatest decrease in the number of passengers was in Banska Bystrica region. There was a decrease in the number of passengers over the period from 104.041 millions passengers to 41.367 thousand passengers. This is a substantial (60.2 \%) decrease between the years 2001 and 2012. Conversely, the lowest decrease in the number of passengers was in Bratislava region, (36.1\%) from 22.743 thousand passengers in 2001 to 14.543 millions passengers in 2012 . The average decrease in the number of passengers for all the regions during the period 2001-2012 is 48.9\%, from 566.445 millions passengers in 2001 to 289.228 millions passengers in 2012 (Fig. 2).

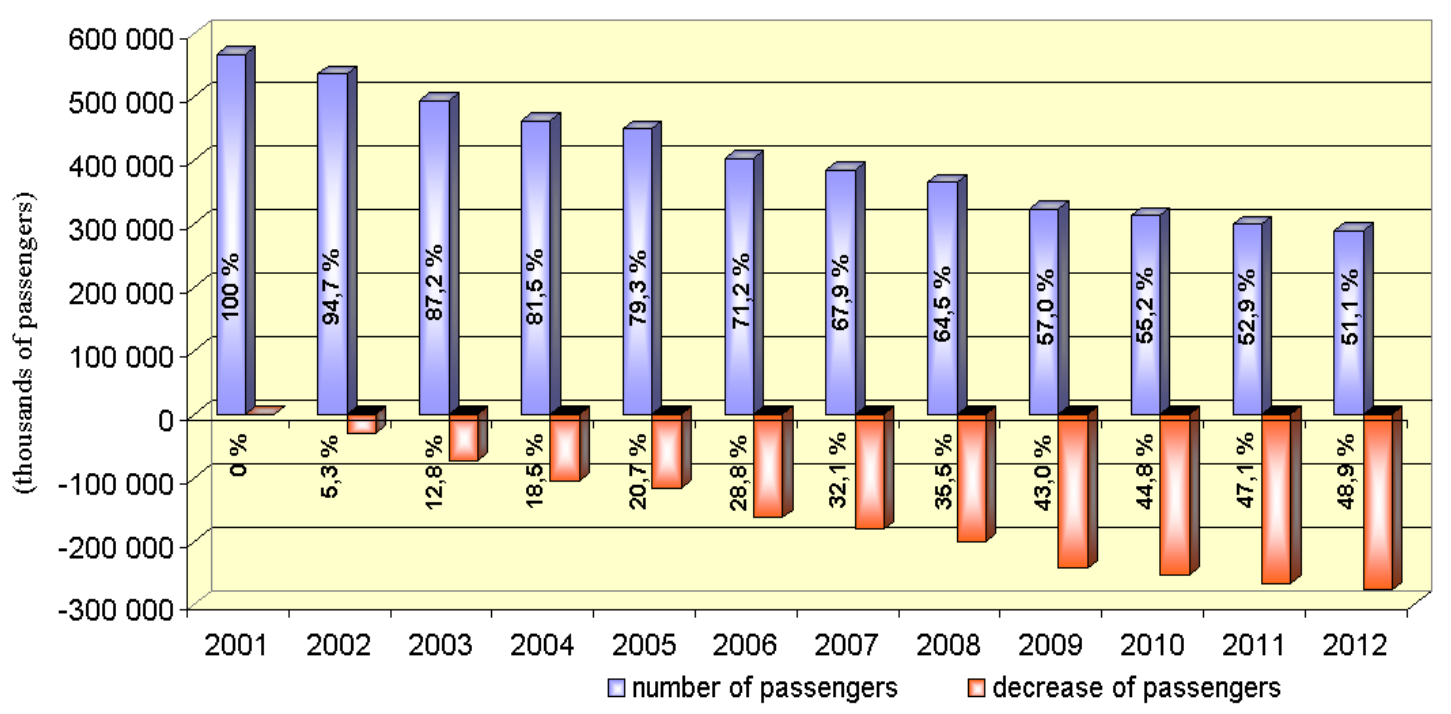

Figure 2. Trend in Number of Passengers in Enterprises, which are Specialised in Road Transport in Regions of the Slovak Republic 
To ensure a serviceable transport system in the regions, regional transport systems operate with different capacities for different means of transport and deal with different passenger demand. It is necessary to monitor also the actual transport performance in millions of passenger-kilometres rather than the number of passengers. There is a comparison of trends in transport performance over several years of monitoring time shown in the Table 3. The greatest decrease in transport performance was in the Presov region. The decrease in Transport performance decreased from 1205 millions of passenger-kilometres in 2001 to 536 millions passenger-kilometres in 2012. This is a substantial decrease of $55.5 \%$. The lowest decrease in transport performance was in the Bratislava region: $24.6 \%$, from 566 millions passengerkilometres to 427 millions of passenger-kilometres. The average decrease in transport performance for all the regions during the period 2001-2012 is $44.5 \%$, from 8253 millions passenger-kilometres in 2001 to 4 584 millions passenger-kilometres in 2012.

Table 3. Number of Transport Performance in the Enterprises Specialised in Road Transport (Millions of Passenger-kilometres)

\begin{tabular}{|c|c|c|c|c|c|c|c|c|c|c|c|c|}
\hline \multirow{2}{*}{ Region } & \multicolumn{12}{|c|}{ Transport Performance (millions of passenger-kilometres) } \\
\hline & 2001 & 2002 & 2003 & 2004 & 2005 & 2006 & 2007 & 2008 & 2009 & 2010 & 2011 & 2012 \\
\hline Bratislava & 566 & 820 & 483 & 511 & 469 & 479 & 478 & 449 & 360 & 364 & 411 & 427 \\
\hline Trnava & 729 & 716 & 665 & 661 & 675 & 771 & 780 & 676 & 521 & 513 & 524 & 506 \\
\hline Trencin & 992 & 974 & 934 & 1006 & 1019 & 971 & 1084 & 706 & 586 & 666 & 645 & 666 \\
\hline Nitra & 1316 & 1411 & 1289 & 1271 & 1192 & 1267 & 1212 & 997 & 785 & 723 & 748 & 712 \\
\hline Zilina & 1055 & 989 & 1096 & 863 & 872 & 818 & 937 & 747 & 620 & 567 & 602 & 615 \\
\hline $\begin{array}{c}\text { Banska } \\
\text { Bystrica }\end{array}$ & 1307 & 1136 & 1082 & 1159 & 1193 & 1232 & 1208 & 954 & 567 & 578 & 603 & 606 \\
\hline Kosice & 1083 & 988 & 1073 & 914 & 942 & 950 & 952 & 836 & 501 & 457 & 528 & 516 \\
\hline Presov & 1205 & 1202 & 1135 & 1497 & 1163 & 1177 & 945 & 1081 & 598 & 568 & 550 & 536 \\
\hline Total & 8253 & 8236 & 7757 & 7882 & 7525 & 7665 & 7596 & 6446 & 4538 & 4436 & 4611 & 4584 \\
\hline
\end{tabular}

Source: The Statistical Office of the SR

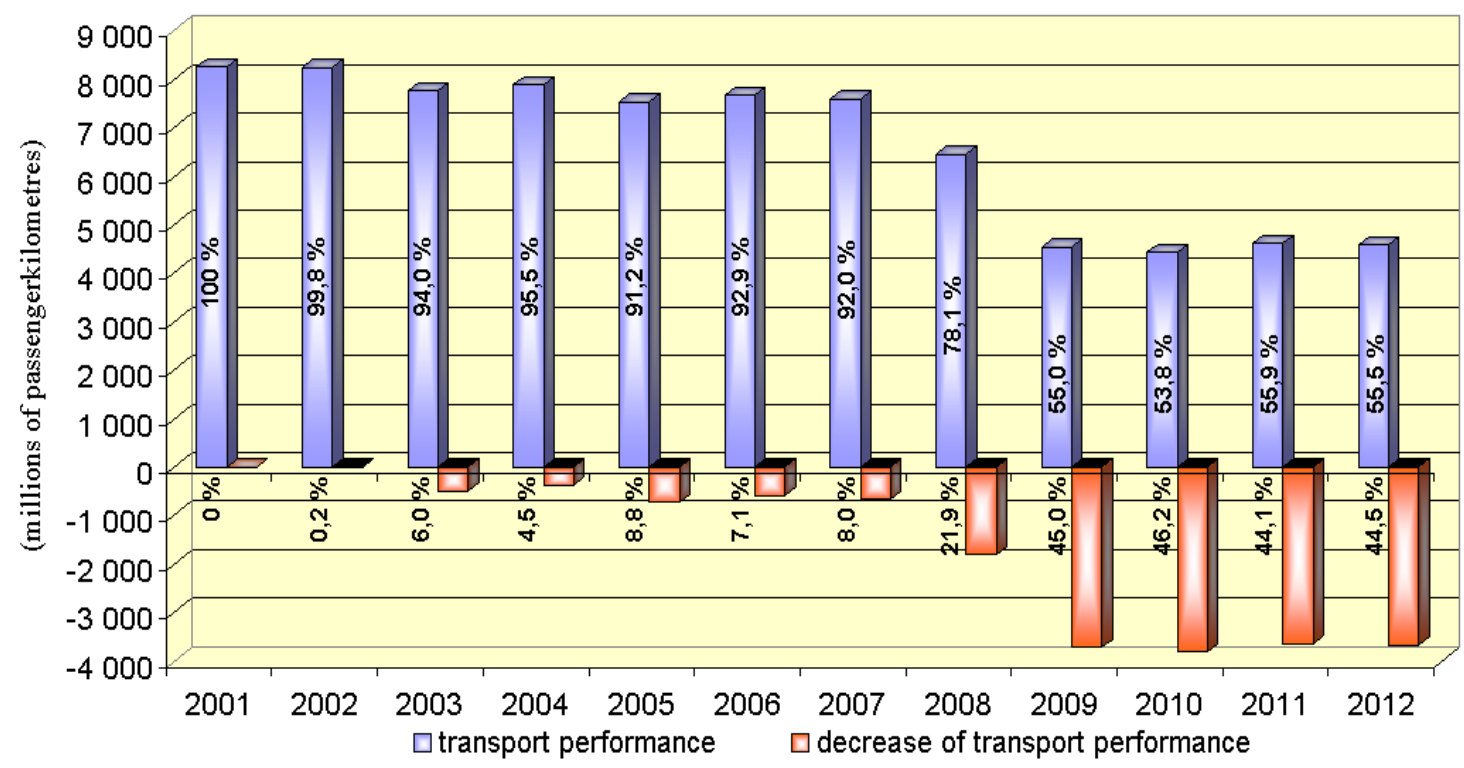

Figure 3. Trends of Transport Performance in Enterprises Specialised in Road Transport in Regions of the Slovak Republic

Figure 3 shows the recorded trend of transport performance in several regions of the Slovak Republic over the years 2001-2012. While the number of passengers carried by organisations specialising 
in road transport in regions of the Slovak Republic decreased overall, transport performance showed a slight upward trend in some years (for example years 2004, 2006 and 2011), a significant decrease was occurred in 2009. In 2012, the transport performance for the regions of the Slovak Republic was at of $55.5 \%$ of the level recorded in 2001 .

\section{Determination of Trend Performance MPT}

The modelling of transportation and transport processes in a major territory unit (region or district) uses the same methods as in towns. On the other hand there are some differences, which must be considered. First of all, there are the size of the modelled area and the volume of requirements for the input data regarding the distribution of activities in the area, and regarding the transport networks. Next, there are the specific characteristics of behaviour of people living in towns or in the country, or in different parts of the area. There are regions where industry, agriculture or recreational use prevails, and they have different social and economic conditions [4].

The succession of steps that allow a forecast in the trend of transport indicators to be determined is represented in the next figure. Input information for choosing the appropriate model for trends and predictions for the selected region (Zilina region) introduces quantified customer requirements to the transport process (indicators of MPT performance). These take into consideration the spatial distribution of the Slovakian territory and the time aspect (time period: years 2001-2012).
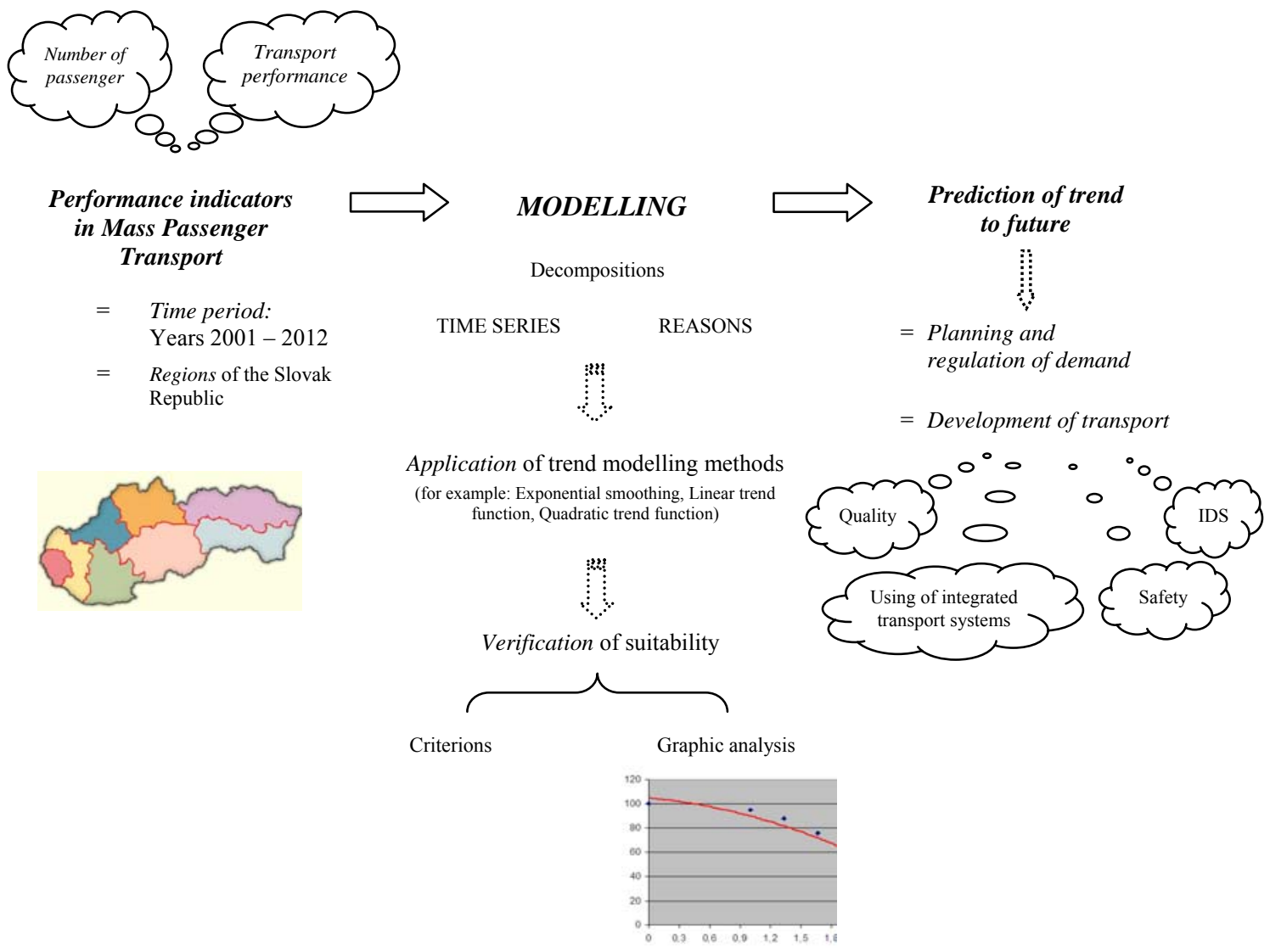

Figure 4. Succession of Steps for Determination of Trend Performance MPT

The correct identification of input information creates the basis for modelling, which is a tool of systemic analysis of complicated problem solving. This can include also the determination of development of investigating indicators prediction. Model choice is influenced by the time series analysis of input information on the basis of decomposition. The main reason for decomposition is the revelation of relations and trend tendencies. The forecast is likely to be more accurate if seasonal variation is removed. The main condition is to represent every single value of the time series that can be represented as a summation or product of its components by single models of the time variable. 
Table 4. View of Selected Prognostic Methods

\begin{tabular}{|c|c|c|}
\hline Exponential smoothing & $\begin{array}{c}S_{t}=\alpha \sum_{k=0}^{N-1} \beta^{k} y_{t-k} \\
\hat{y}_{t}=a_{0,(t-1)}+a_{1,(t-1)} \cdot \tau \\
\text { where } \tau=1\end{array}$ & $\begin{aligned}= & \text { form for exponential average } \\
= & \text { exponential smoothing is suitable for modelling of } \\
& \text { time series with fluctuations. The greatest weight is } \\
& \text { attributed to the youngest observation. } \\
= & \text { weight decreases exponentially with time. The rate of } \\
& \text { smoothing is dependent on the size of the smoothing } \\
& \text { factor } \alpha . \text { Brown's double exponential smoothing and } \\
& \text { Holt exponential methods are suitable for the local } \\
& \text { linear trend in time series, }\end{aligned}$ \\
\hline Linear trend function & $T_{t}=A_{0}+A_{1} \cdot t$ & $\begin{aligned} &= \text { are regression models, where the independent variable } \\
& \text { is time, respectively its modification. } \\
&= \\
& \text { trend functions are appropriate for a uniform values } \\
& \text { over the time series, } \\
&=\quad \text { where } \mathrm{A}_{0}, \mathrm{~A}_{1} \text { are parameters of the regression } \\
& \text { relationship }\end{aligned}$ \\
\hline Quadratic trend function & $T_{t}=A_{0}+A_{1} \cdot t+A_{2} \cdot t^{2}$ & $\begin{aligned} &= \text { are regression models, where the independent variable } \\
& \text { is time, respectively its modification. } \\
&= \\
& \text { trend functions are appropriate for a uniform values } \\
& \text { over the time series } \\
&=\text { where } \mathrm{A}_{0}, \mathrm{~A}_{1}, \mathrm{~A}_{2} \text { are parameters of the regression } \\
& \text { relationship }\end{aligned}$ \\
\hline
\end{tabular}

The choice of the optimal method in terms of exactness of processing and accuracy is conditioned not only by theoretical knowledge of the selected method but also by a considerable amount of experience and subjectivity. Achieved outcomes should be the starting point for the process of making important decisions in a firm [5].

The application of selected methods represents a choice of appropriate trend function for a given time series on the basis of realized decomposition and estimated attributes of development with respect to examined problems. Model parameters will be estimated from the value time trend. In case we should initiate presumption parameters, the complete condition of importance can be used to determine the forecast.

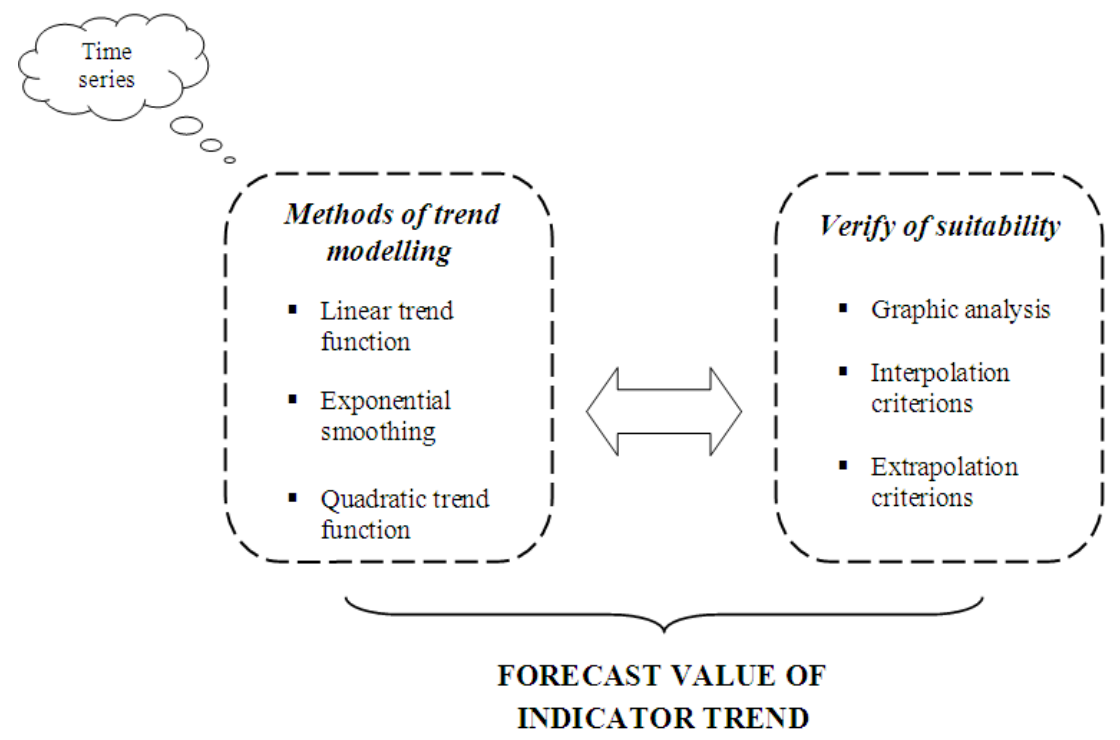

Figure 5. Succession of Steps for Forecast of Indicator Trend

The verification of the appropriateness of the applied methods is realized on the basis of an adjudication of selected criteria because of the reason of measure precision; smoothing finding or average value residues characteristics introduces value RMSE. 


$$
R M S E=\frac{1}{N} \sum_{t=1}^{N}\left(y_{t}-\hat{y}_{t}\right)^{2},
$$

where: $y_{t} \sim$ variance of real trend value,

$\hat{y}_{t} \sim$ smoothing - estimated trend value,

$R M S E \sim$ Root Mean Square Error.

Consecutively after evaluation of reached results quantities, value of future trend investigating indicators follows the period of the year 2013.

Table 5. Indicators of MPT of Zilina region at the Period of Years 2001-2013

\begin{tabular}{|c|c|c|c|c|}
\hline \multirow[b]{2}{*}{ Year } & \multicolumn{2}{|c|}{ Value of MPT indicator } & \multicolumn{2}{|c|}{ Predictions of MPT indicator } \\
\hline & $\begin{array}{l}\text { Number of } \\
\text { passengers } \\
\text { (thousands of } \\
\text { passengers) }\end{array}$ & $\begin{array}{c}\text { Transport Performance } \\
\text { (millions of passenger- } \\
\text { kilometres) }\end{array}$ & $\begin{array}{c}\text { Number of passengers } \\
\text { - by methods } \\
\text { exponential smoothing } \\
\text { (thousands of } \\
\text { passengers) } \\
\end{array}$ & $\begin{array}{c}\text { Transport Performance } \\
\text { - by methods linear trend } \\
\text { function } \\
\text { (millions of passenger- } \\
\text { kilometres) }\end{array}$ \\
\hline 2001 & 89076 & 1055 & 89799.8 & 1085.45 \\
\hline 2002 & 86408 & 989 & 84405.1 & 1035.02 \\
\hline 2003 & 79103 & 1096 & 79334.6 & 984.582 \\
\hline 2004 & 73437 & 863 & 74568.6 & 934.145 \\
\hline 2005 & 69187 & 872 & 70089.0 & 883.709 \\
\hline 2006 & 66704 & 818 & 65878.5 & 833.273 \\
\hline 2007 & 62926 & 937 & 61920.9 & 782.836 \\
\hline 2008 & 58975 & 747 & 58201.1 & 732.4 \\
\hline 2009 & 52904 & 620 & 54704.7 & 681.964 \\
\hline 2010 & 50332 & 567 & 51418.4 & 631.527 \\
\hline 2011 & 49745 & 602 & 50332.3 & 600.154 \\
\hline 2012 & 50918 & 615 & 49745.1 & 552.577 \\
\hline 2013 & - & - & 50917.9 & 505.01 \\
\hline
\end{tabular}

Values of transport performance time series reached relatively periodic trend in monitored period of years 2001-2012.

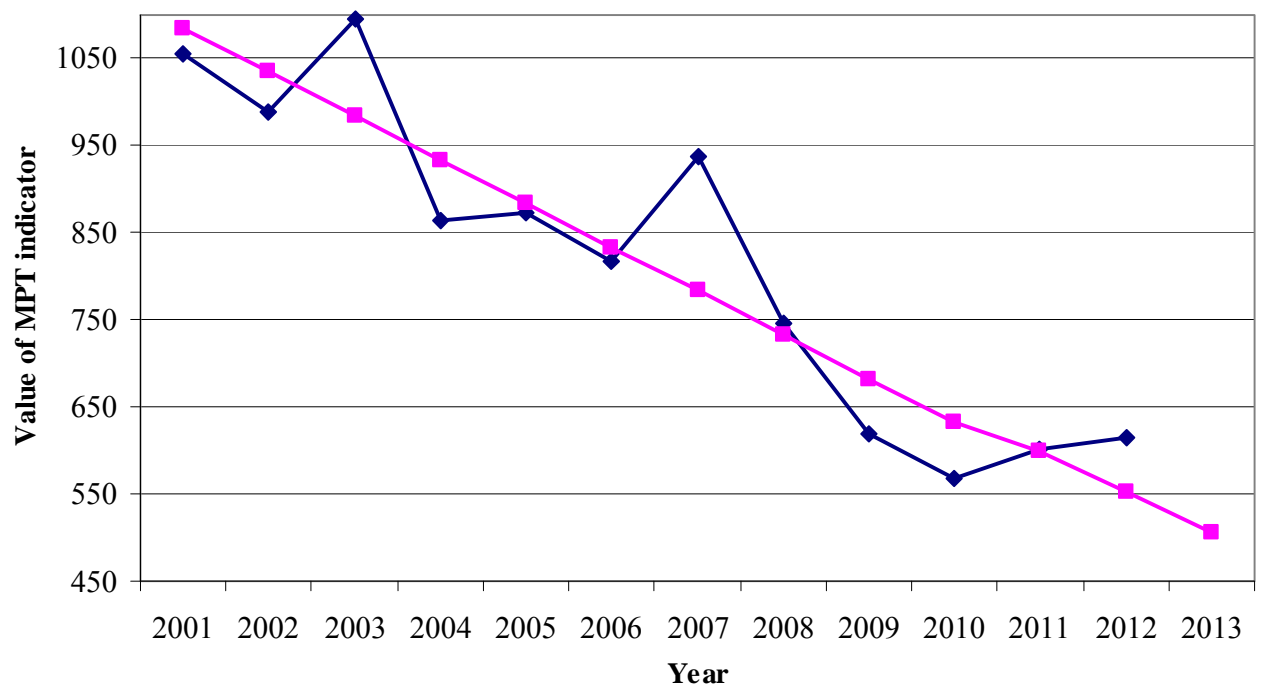

$\multimap$ Transport Performance (millions of passenger-kilometres)

$\rightarrow$ Predictions of MPT indicator - Transport Performance - by methods linear trend function

Figure 6. Predictions of MPT Indicator - Transport Performance of Zilina region 
To initiate the regulated time period, the service methods were used on the basis of graphic analysis adjudication Quadratic trend function, Holt's exponential smoothing and methods of Linear trend function and methods of exponential smoothing. After the application of the time series, the verification of the appropriateness of single methods by selected criteria followed.

As the most appropriate method to describe the trend of the time series methods in the best way, methods of Linear trend function has been evaluated because, according to determined criteria, it recorded the lowest value of RMSE (75.6364) and all model parameters were important. Other applied methods had no important model parameters; and so it is not possible to recommend the application of these methods (methods of Holt's e exponential smoothing and exponential smoothing).

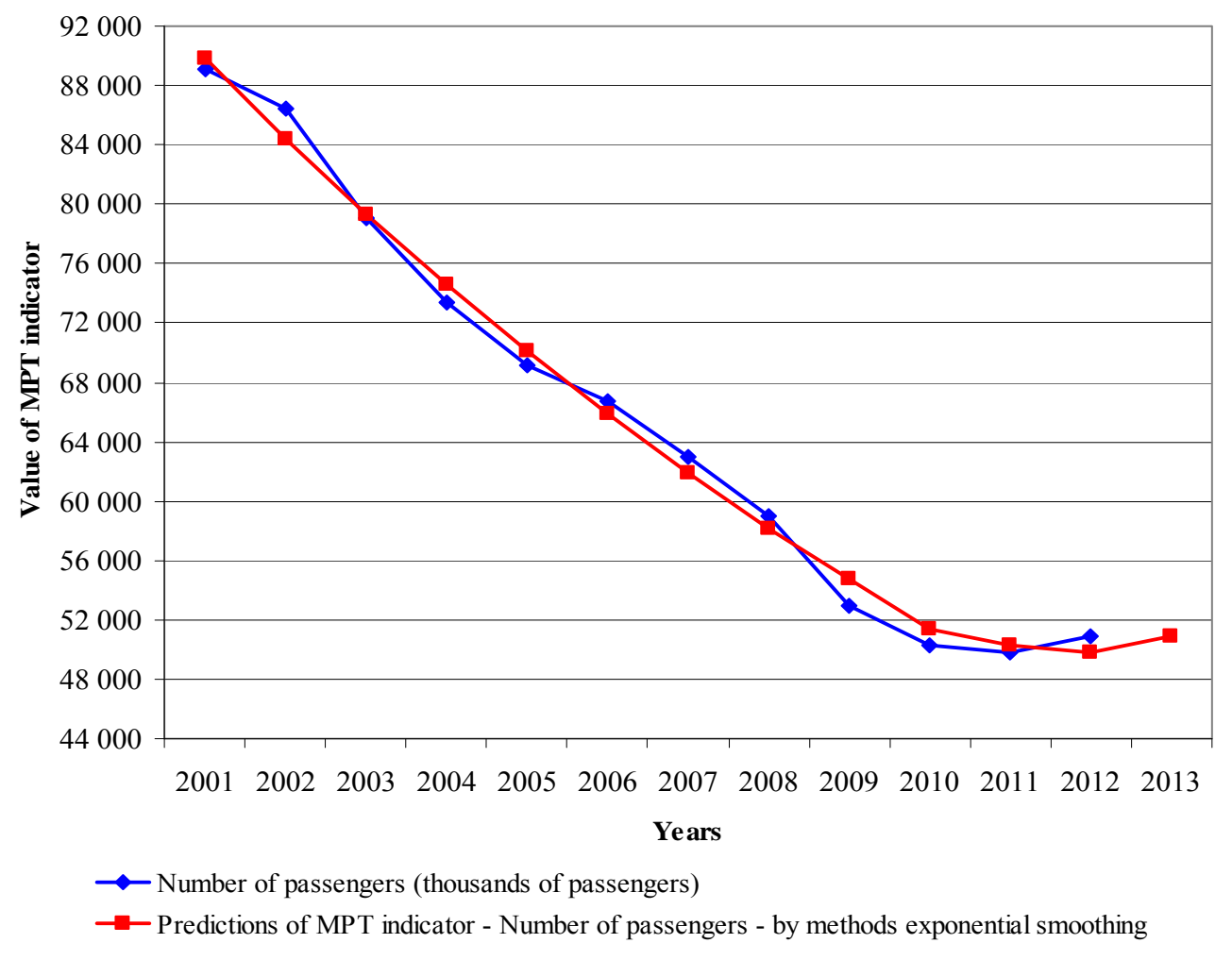

Figure 7. Predictions of MPT Indicator - Number of Passengers of Zilina region

Number of passengers by using the method of exponential smoothing the best results were achieved and the forecast values for the year 2013 were quantities of 50917.9 thousands of passengers.

\section{Conclusions}

Transport is one of the basic sectors that significantly affect socio-economic development and increases in living standards. This makes it one of the key factors in the development of each society. It is not a goal in itself, but a means of economic development and a prerequisite to achieving social and regional cohesion [1].

Transport management concentrates on assessments of measures of the requirement for convenient transport, the requirements for a particular type of transport and transport service and maintaining or extending the existing market for transport.

In transport management it is necessary to create a modern structure and procedure for managerial work. The implementation of those appropriate prognostic methods and planning models allows the determination of the planned value of supply and demand by evaluating the time series trend, thereby introducing a possible way to realise stable and long-time results for the regional transport enterprise activities. In addition it could enable the application of intelligent transport systems, the integration of transport systems and improved safety and quality of service with higher value-added.

Accomplishment of fundamental functions and operations of populate regions and city depends on mass passenger transport that must ensure all necessary transport requirements. To forefront extends 
distinctively strongly urgency of good coordination of all operations in complete transport systems in conditions increasing transport requirements and demands to regions and cities development [3].

Essential is in the process coordination otherwise self-contained participants (municipalities, cities, interest groups, natural person, juristic person, etc.) and place/put/lay emphasis on creativity, communication ability, ideas richness, engagement, effort to solve problems, flexibility, persuasion and natural authority [1].

In regional management is necessary to create modern and elementary procedure and structure of managerial work. Just implementation of appropriate prognostic methods and planning models those allow determining planned value of supply and demand by evaluation of time series trend introduces to possible solution to reach stable and long-time results of region and transport enterprise activities and also to application of intelligent transport systems, integrate transport systems, safety and quality of services.

Regional management of area can allow to Slovak regions and municipality fast adaptation to conditions EU market as innovation and integrated management tool. Regional management can help to break through and assume to market with competitive supply that to Slovak gives new human and financial capital and ensures so long-term perspective and permanent sustainable development.

\section{References}

1. Dicová, J., Ondruš, J. (2010). Development of Public Passenger Transport in the Slovak Republic between Individual Road Transport. (In Slovak). Railway Transport and Logistics, VI(1), 33-38. ISSN 1336-7943. Žilina: FPEDAS, University of Zilina.

2. Kalašová, A., Pal'o, J. (2003). Traffic Engineering - Organization and Transport. (In Slovak). Zilina: University of Zilina, 165 pp. ISBN 80-8070-076-1.

3. Kalašová, A., Surovec, P. (2003). Sedated Transport. (In Slovak). Zilina: University of Zilina, EDIS, 202 pp. ISBN 80-8070-076-1.

4. Ondruš, J., Pal'o J. (2007). The Modelling of Transportation and Transport Processes of the Region of Zilina. In Advances in Transport Systems Telematics 2: Section V: Systems in Road Transport (pp. 2937). Katowice: Silesian University of Technology. ISBN 978-83-917156-6-6.

5. Pančíková, L. (2007). Application of Prognostic Methods in Transport. Journal of Information, Control and Management Systems, 5(2/2), 309-318. ISSN 1336-1716. Zilina: Faculty of Management Science and Informatics, University of Zilina.

6. Poliak, M., Konečný, V. (2009). Market of Mass Public Transport and its Financing. (In Slovak). Zilina: University of Zilina, 176 pp. ISBN 978-80-8070-999-0.

7. Poliaková, B. (2011). Conditions and Proposals of Tariff Integration for the Integrated Transport Systems in the Slovak Republic. Transport and Telecommunication. 12(2), 39-49. ISSN 1407-6160.

8. The Statistical Office of the Slovak Republic - www.statistics.sk

9. http:/www.emergency-slovakia.sk/krajske-operacne-strediska-zachrannej-zdravotnejsluzby.html?page_id=144 - article about emergency in the Slovak Republic

\section{Acknowledgements}

This contribution is the result of the project implementation:

Centre of Excellence for Systems and Services of Intelligent Transport II, ITMS 26220120050 supported by the Research \& Development Operational Programme funded by the ERDF.

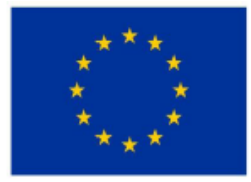

Európska únia

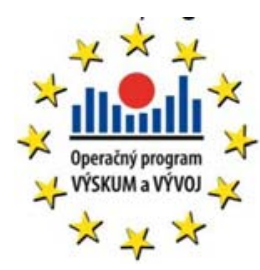

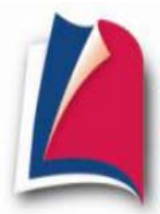

Agentúra

Ministerstva školstva, vedy, výskumu a športu SR pre štrukturálne fondy EÚ

"We support research activities in Slovakia / Project is co-financed by the EU [Podporujeme výskumné aktivity na Slovensku/Projekt je spolufinancovaný zo zdrojov EÚ]" 